UDC 338.43.02:631.152 (4/9 (477)

(C) 2017

J. Gadzalo, Academician of the NAAS, Doctor of Agricultural Sciences

Yu. Luzan, Corresponding Member of the NAAS, Doctor of Economic Sciences

National Academy of Agrarian Sciences of Ukraine

\title{
MODERN CALLS AND REMODELING AGRARIAN POLICY OF UKRAINE
}

The purpose. To justify necessity of development of agrarian policy of Ukraine with the purpose to create favorable conditions for competitive development of agrarian sector of economy and solution of problems of vital activity of countrymen. Methods. Methodological and theoretical basis of the paper is the legislation of Ukraine, generalization of domestic scientists and the advanced world experience in formation of agrarian policy. Results. Basic components of agrarian policy of the state, as well as problem questions and directions of development of land relations, formation of agrarian sector are delineated. Ways of perfecting the system of financial-credit provision, price, tax and budgetary regulation of agrarian economy are offered. Methods are offered which should seize existence of shadow economy and limit monopolism in agrarian market. The important feature of modern agrarian policy should become the obligatory count of the demands of the Agreement on association between Ukraine and the European Union and realization of processes of decentralization of authority in the state.

Conclusions. Results of researches can be a basis for formation of the balanced state agrarian policy for stable development of agrarian sector of economy and village terrains.

Key words: agrarian sector, village terrains, balanced agrarian policy, agriculture, land relations, food safety.

Problem statement. Ukrainian agro-food sector stability, development of rural areas and the improvement of the living conditions of the rural population is affected by a large number of interconnected factors, which are still unstable, unbalanced, and in many cases contradictory.

Research confirms that the agricultural reforms carried out during the independence of Ukraine, due to their incompleteness, were insufficient for the competitive development of the agricultural sector. When adopting laws, the peculiarities of functioning and modern tendencies of agriculture economic development are not always taken into account. Not yet created the necessary conditions for the implementation of appropriate structural changes in agroindustrial production, aimed primarily at providing physiological (rational) norms of food consumption for the population. The physical and economic access to vital quality food products is not ensured. For the agricultural sector, the system of 
financial and credit support, price, tax and budget regulation should be improved, favourable conditions for the competitiveness of small agricultural producers, as the basis for the formation of the middle class in the village and the preservation of the Ukrainian village, should be developed. The market infrastructure should be developed mainly on the principles of cooperation, barriers to prevent the shadow economy and unfair competition, the restriction of monopoly, the establishment of public control, intra-industry and inter-farm self-regulation.

Special government attention should be paid the development of land market relations in the interests of peasants and rural communities. The main goal of market reform that is the creation of an effective host on the land has not been achieved. Prevention of negative tendencies of the irregular concentration of agricultural land to individual users has not become a rule, which, along with other negative phenomena, can lead to a 'point of no-return' from the latifundium course of development, to the loss of a unique rural settlement network of Ukraine that does not have analogues in the world.

Such a situation, despite some positive changes being a result of already carried out market reforms to increase the volumes of production and export of agricultural products, distorts the development of the agricultural sector and the agricultural market, leads to loss of jobs, causes poverty and degradation of the rural population, the decline in the rural social sphere, deteriorates natural environment. Negative phenomena already hinder the positive tendencies of the agricultural sector development and in the long run, they can turn it from a recognized 'locomotive' of the modern national economy into a problematic 'wagon', which must not happen.

These and other negative trends are the results of the imperfect state social economic policy regarding the agricultural sector. The competitive development of agri-industrial activity must be integrally supported, social and economic problems of rural inhabitants must be solved, and favourable conditions must be created for the development of the rural area as it, for example, is defined by the Common Agricultural Policy of the EU and the FAO principles of rural development.

Mandatory consideration of requirements related to the need to implement the Association Agreement between Ukraine and the EU should become an important feature of the formation of a modern state social and economic policy related to the implementation of processes for decentralization of state.

The art of state administration consists of creating a stable systemic interaction of all factors of the agricultural and rural development, which can be achieved through the development of a balanced agricultural policy, clearly defined and fixed in domestic legislation. Further development of the national model of agricultural policy should take into account the peculiarities and current 
trends of the sector and rural areas using the best world experience, maximally contribute to ensuring the real food security in the country, the development of exports of agricultural products with high added value and the creation of proper living conditions in the rural areas.

Analysis of recent research and publications. A significant contribution to solving the problems of the agricultural sector was made by well-known domestic economists V. G. Andriichuk (Andriichuk et al., 2005), P. I. Gaidutskyi (Gaidutskyi, 2015), V. M Heiets (Heiets, 2016), Yu. E. Gubeni (Gubeni, 2015), M.V. Hladii (Hladii et al., 2011), V. T. Dudar (Dudar, 2016), I.H. Kyrylenko (Kyrylenko et al., 2008), M. F. Kropyvko (Kropyvko et al. 2008), Yu. O. Lupenko (Lupenko et al., 2014), A. A. Mazaraki (Mazaraki et al., 2010), M.Y. Malik (Malik \& Shpykuliak, 2010), V. Ya. Mesel-Veseliak (Mesel-Veseliak \& Fedorov, 2016). Sabluk (Sabluk, 2015, 2016), B. Y. Paskhaver (Paskhaver, 2001), M. Ya. Khorunzhyi (Khorunzhyi, 2003), V. V. Yurchyshyn (Yurchyshyn, 2013), et al.

There are many discrepancies in the views of individual researchers on the principles of formation and the economic essence of agricultural policy that requires further research.

The purpose of the research was to investigate the essence of the state agricultural policy, its importance for the social and economic security of the state, and to propose ways to systematically ensure the effective development of agricultural sector and rural areas.

Results. In the state agricultural sector, complex transformational processes aimed at the full development of market conditions of economic activity have been going on. Their complexity is determined by a number of factors. First of all, it is necessary to solve complex problems of agricultural development and interconnected food industry, processing of agricultural raw materials, development of related branches of the economy (agricultural machinery, chemical, textile and other industries), bioenergy, agrarian science and education, the entire logistic system of product promotion from producer to consumer, limiting the negative impact of natural and market risks, ensuring environmental requirements for the organization of economic activities, preservation of soil fertility, protection of lands, etc. All this together forms a system that will ensure food security of the Ukrainian population, increases in the volume of agricultural export and, to a large extent, by forming a socially oriented agricultural economy will ensure the life-support of 13.2 million rural men [15].

The effectiveness of market transformations depends on such efficiency and flexibility of the state measures that, on the one hand, would take into account the current trends in the domestic agricultural market and the specifics of the world food system development where Ukraine has already been accepted and relied on 
as a potential and significant supplier of agricultural and food products into the international market; on the other hand, it would resolve interconnected problems of the rural areas development, appropriate social and economic life support conditions for rural residents and formation of a wealthy village community, without which, as practice shows, the development of rural settlement network is impossible.

Solving these problems will contribute to the construction and effective functioning of public administration in various areas of the formation and implementation of social and economic policy. Well-balanced state policy is now especially needed for the development of a complex and important sphere of human activity that is agriculture, and where the most critical problems of socioeconomic development of the state have accumulated. Their solution should be considered in the context of improvement of public administration, taking into account the peculiarities of functioning and the current state of the agroeconomy, in particular, through the decentralization of power and the approval of appropriate well-considered regulations. One example of ignoring this condition is the adoption of the Commercial Code of Ukraine, where, without taking into account agricultural features and world experience, the way for the creation of large monopoly economic structures in the agriculture was paved, in particular, for agroholdings, which until recently were prohibited. In addition, due to the shortcomings in the legislation, there is still a lack of regulation on intermediary structures for the provision of various services, especially to small agricultural producers that do not have common economic interests. At the same time, the legislation on the establishment of a complete system of civic organizations aimed at ensuring reliable public control in the agricultural sector, organization of interbranch and intra-industry relations on the principles of self-regulation and the development of public-private partnerships, as is practiced in the EU countries, is constrained. All these and other negative phenomena have led to the formation of a harmful to rural areas and society agricultural system, suppression of small producers, including farmers and individual husbandry, blocking the development of service agricultural cooperatives, the unregulated concentration of land owned by individual users, which is not allowed in the economically developed countries. Such actions contributed to the progression of monopoly and corruption in the agricultural market, conditions for lobbying the interests of individual market participants in the government, which ultimately forms a distorted one-sided export-oriented agriculture economy, an irrational structure of agro-industrial production with an orientation towards a preferential increase in production volumes of grains, sunflower and sunflower oil, rape, soya, that is, the most export-oriented products, which in turn led to predatory land exploitation, 
violation of agro-ecological requirements, a sharp decrease in rural, and degradation of the social sphere of villages.

A high proportion of business entities that form the nationwide market of agricultural and food products, ensure gross domestic product, value-added products, payments to the state budget, commodity structure of exports and employment, and especially the presence of significant unused potential development opportunities, indicate the need for adequate concentration of attention by the state, research and other institutions on creating more favourable conditions for increasing their competitiveness on both domestic and foreign agricultural markets.

For the development of the tactics and strategy of public administration in the agro-economy of the country, there are such concepts as 'agricultural sector of the economy', 'rural areas', 'state agricultural policy', i.e., a set of state measures aimed at ensuring effective development. There are different interpretations of the definition of data concepts. It is possible to follow the evolution of the names of the central executive body of Ukraine in the post-Soviet period, which is responsible for the food supply of the state - from Derzhahroprom to the Ministry of Agriculture and Food, agro-industrial complex, agricultural policy to the current Ministry of Agrarian Policy and Food. During the period of independence, the sphere of influence of this central body of state administration was constantly changing, various subsystems of economic, scientific, pedagogical and other spheres of activity were excluded or supplemented, features of the function were constantly changing, but so far, according to many experts, the optimal variant has not been found. Currently, significant structural, economic, social and other changes are taking place in the organization of agro-industrial activity and the status of rural areas. Unfortunately, in many cases this central executive authority, primarily because of the imperfection of the national system of governance, is late or proposes not always well-grounded mechanisms for regulating socio-economic processes, in particular such basic issues of agro-industrial activities as land reform, the formation of the agricultural market infrastructure, including the functioning of a transparent exchange market, as an important tool for determining price indicators, the development of serving agricultural cooperatives, improvement in the tax system, antimonopoly regulation, solving social problems of the villagers.

Despite the presence of these and other shortcomings, the significant positive matter was that in the process of market transformations, fundamentally new economic entities on the basis of private land ownership appeared that mainly operate private enterprises throughout the chain of processing and promotion of food to end users, to a certain extent the system of expert and personnel support is 
maintained, the development of the market continues along with the development of an appropriate market infrastructure, etc. This has already given a feedback and intensified economic activity in the agricultural sector. The production of agricultural products in 2016 compared with 1999 (the period of active reformation in the agrarian sector) has grown 1.8 times, technical re-equipment and development of modern technologies in the food industry has improved significantly, in agriculture, and fisheries, the development of market management and marketing has revived, and the foreign economic activity has been intensified.

As a matter of fact, the base of agro-industrial activity constitutes of agricultural entities, including farmers and individuals and other small producers who produce a critical mass of agricultural products for the needs of the internal food market. In our opinion, agriculture, as the basic component of the food supply, should define the name of the system of agro-industrial activity. Recently, the most used in the scientific environment and legislation is the concept of 'agrisector', which in Latin means 'agriculture'. These terms are frequently used synonymously. It should be kept in mind that the processes of integration with the world food system require compliance with the principle of certain unification of such and other terms. In many countries of the world, particularly in the EU countries, forestry is attributed to the agricultural industry. Apparently, on the basis of these considerations, forestry is now also attributed to the management of the Ministry of Agrarian Policy and Food of Ukraine, and the relevant integral statistical surveys are carried out.

Consequently, the interpretation of the term 'agricultural sector' logically determines the system of economic activity, which includes: rural, fish and forestry; food industry and processing of agricultural products; the harvesting, storage, transportation and sale of agricultural and food products; expert and personnel support.

Solving problems of rural areas requires special state attention state. During the period of Ukraine's independence, the deterioration of social and living conditions of the rural population has been observed along with dying out of rural settlements, loss of job opportunities, deterioration of the environmental situation, use of local natural resources, etc.

The significant disadvantage of public administration in Ukraine is the longterm uncertainty of the functions of central executive authorities in solving the problems of social and rural development. A strategic mistake in the development of rural areas was the elimination of such functions from rural communities and the restriction of their influence only to the territories of rural settlements.

These mistakes have disrupted the field of state administration, where agricultural activities were closely linked to land, forest, water and other natural 
resources and, at the same time, were an important component of the life-support for rural residents. It also led to the humiliation of the role of the human factor, first of all rural men, as a social group of people who are not only the main source of labour for existing enterprises in the agrarian sector and other spheres of the economy in rural areas, but also produce agricultural products in their individual households for self-provision in and selling in the domestic food market. A necessity to create the basic conditions for the physical and spiritual development of rural residents is out from the attention of the state, as well as the restoration of the workforce, creation of additional jobs, first of all, by stimulating the development of small and medium agricultural entrepreneurship, restoration of local crafts, objects of social development of rural settlements, supporting the development of agricultural servicing cooperatives etc.

At present, the appropriate processes of power decentralization are going on, united territorial communities are being formed, and functioning of central and regional executive authorities and local self-government is improving which are aimed at improving state governance in the development of rural areas. But these processes should be more dynamic and systematic, supported by the establishment of fair intergovernmental fiscal relations, giving territorial communities effective powers to control the use of local natural resources and providing opportunities for certain influence on the regulation of the economic activity of business entities in the respective territories.

In the research papers, the terms 'development of rural areas' and 'rural development' are frequently used. They can also be considered synonyms as rural population, ecology, use of land and other natural resources, all social, industrial, transport and interconnected infrastructure of the respective rural areas are not only the territory of rural settlements but the basis for rural development.

In our opinion, the interpretation of the term 'rural areas' should take into account the territory defined by the legislation of the rural settlements and the territory beyond their borders, which combines the administrative-territorial combination (villages, settlements, and, in some cases, cities united in the respective territorial communities) and territorial-functional affiliation of agricultural production, processing of agricultural raw materials, preservation of products, its transportation and realization and a system of life-support for population) where the appropriate conditions for work, recreation and spiritual development of the rural population should be created.

It should be noted that the establishment of united territorial communities is not yet fully regulated by the current legislation, in particular, the administrativeterritorial division, the simultaneous functioning of executive bodies of local selfgovernment and local state administrations, etc. Of course, such inconsistencies 
will eventually become another obstacle to effective state governance of socioeconomic processes.

In the socio-economic life of the country, the terms 'agricultural sector' and 'rural areas' cannot in this sense act as final and complete. Functioning of this important human sphere, including economic activities is closely integrated into the integrated system of national political, organizational, financial, environmental, labour and other relations.

It is almost impossible to establish a clear line between them and other spheres of activity during the period of rapid agrarian transformations, the development of national and global processes, international integration and cooperation, changes in the state of the environment, including climate change, the development of science and technology, and the intensification of the knowledge dissemination. Therefore, they should be considered as permanent, which should be systematically specified in their dynamic process and considered situational for certain stages of socio-economic development of the state. It's time to clarify the name and function of the Ministry of Agrarian Policy and Food of Ukraine, giving it appropriate power for the development of rural areas, as it can be seen in the most developed countries of the world.

The conceptual definition of the term 'agrarian policy' is extremely important since it must create favourable conditions for the development of the agricultural sector and rural areas, and to some extent be identified within the Common Agricultural Policy of the European Community.

In this context, a number of other terms (concepts) and their interpretations are intertwined which include the following:

- government management of the agricultural sector;

- state regulation of the agricultural sector of the economy;

- regional agricultural policy;

- corporate and private management of agricultural activities;

- self-government and self-regulation in the agricultural sector.

Having analysed these concepts, it can be argued that they are most likely to fill term 'agricultural policy' and, to some extent, are its components. The components should be interconnected and balanced.

Each of the institutional directions is regulated by separate laws which determine the procedure for forming the system of state and regional management bodies of the agricultural sector, local governments, regulate types of economic entities, establish the regulation for economic relations, form a system of state financial support of producers, determine the taxation system and other economic and administrative incentives and restrictions, regulate the procedure for the establishment and definition of the role of public organizations in matters of self- 
management and self-regulation in the agricultural sector and other areas of economic management and social processes taking place in the agricultural sector and rural areas.

The term 'agricultural policy' should be used as a component of the state socio-economic policy, to define a set of balanced principles, goals, priorities and legal, socio-economic and organizational measures aimed at ensuring food security, protecting the interests of villagers, agricultural business, sustainable development of the agricultural sector and rural areas.

From this interpretation, it follows that agricultural policy should have two components:

- definition of principles, tasks, and priorities;

- development and application of measures and mechanisms that will ensure the implementation of these defined tasks and priorities on the basis of observance of the principles established by the relevant rules, incentives and restrictions in the actions of economic entities, and the continuous monitoring of social and economic processes with a view of the appropriate reaction of public administration and self-government bodies.

Achievement of the determined goal for the development of the agricultural sector of the national economy and sustainable development of rural areas depends on the balance of, on the one hand, tasks and priorities, and, on the other, the system of state measures, which must be backed up by the necessary financial, material, labour and other resources, as well as the corresponding political, administrative and organizational actions. The maximum effectiveness of agricultural policy can be calculated in the case of ensuring synergy of all factors of agricultural development, including the stability of the mechanisms of state regulation of the agricultural economy. Unfortunately, according to various estimates, such a balance in the agricultural sector in the state has never been achieved.

This can be confirmed by the volatility of the agricultural production growth rate of. During the period from 2000 to 2014, the average annual growth rate of agricultural production amounted to $5.3 \%$, and then in the last 3 years, it decreased to $0.4 \%$ (sees Figure). Compared to 2012, the decline in livestock breeding started (by 4.4 billion UAH), and there is an instability in production in other crisis subsectors of agriculture.

Figure. Dynamics of agricultural production of Ukraine including all categories of husbandry at the constant prices of 2010 (billion UAH) 


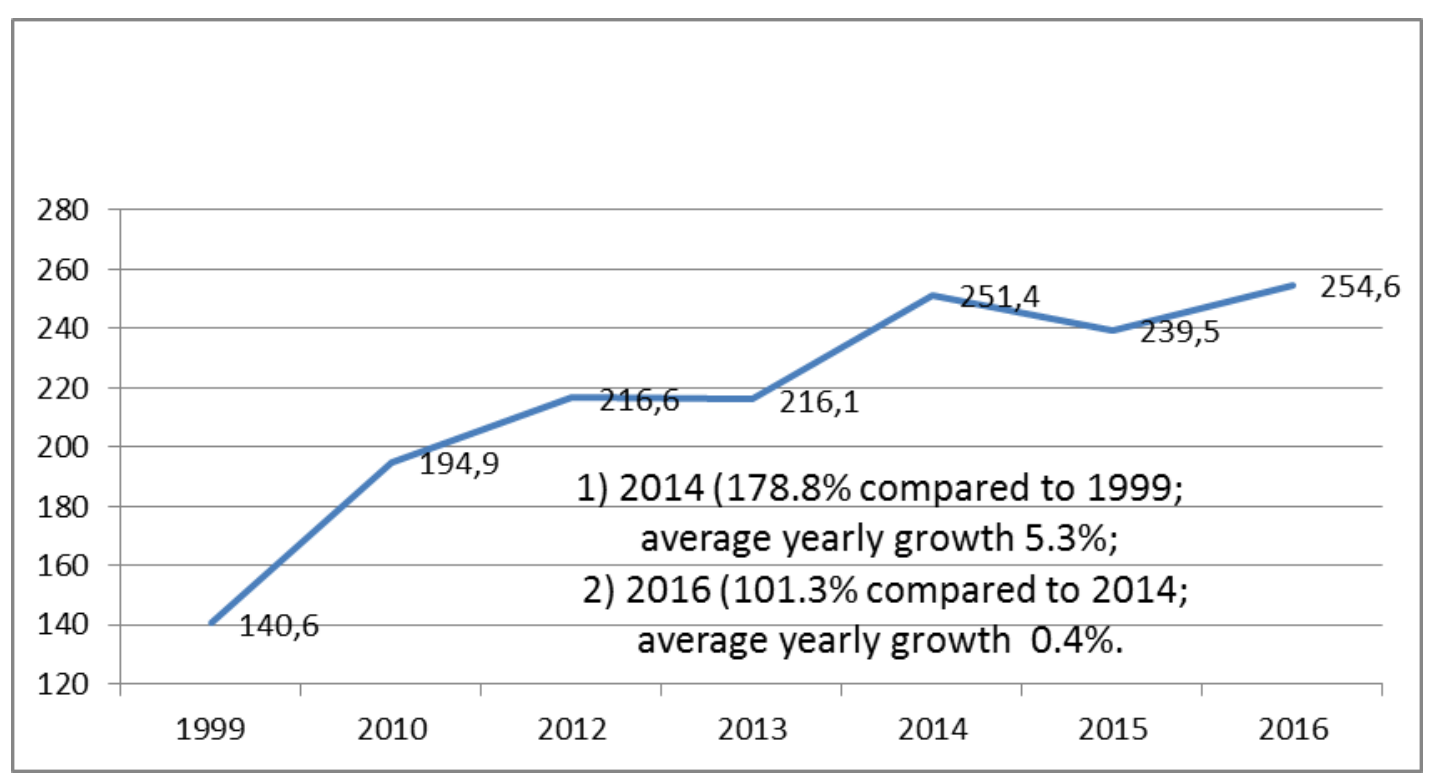

Source: data of the State Statistics Service of Ukraine of 2016 processed by the authors

The fact that in the most profitable industry (101.9 billion UAH in 2015, 89.3 billion UAH in 2016), salaries of agricultural workers in recent years made up $70-75 \%$ of the average salaries in the national economy, which as a whole has negative financial results. One may have an impression that the profits of enterprises in agriculture are being formed through the artificial limitation of salaries and other social charges. Undoubtedly, these statistics require in-depth research.

Loss of traditional markets for the export of agricultural products to the countries of the former Soviet Union and a shift towards more competitive markets in the EU and other developed countries is accompanied by a deterioration of the overall structure of exports, in particular, a decrease in the share of products with high added value. In 2016, as compared to 2010, according to the State Statistics Service of Ukraine, the share of exports of ready-made food products decreased by $9.9 \%$, fats and oils of vegetable and animal origin by $0.4 \%$, livestock and products of animal origin by $2.7 \%$, with the growth of exports of unprocessed soya, rape and other plant products by $13 \%$. At the same time, the domestic market increased by $1.1 \%$ the consumption of imported agricultural products with high added value. That is, Ukraine loses real value added on such trends, which, moreover, indicates the low competitiveness of domestic, ready for consumption, food products in foreign markets (Table 1).

Table 1. Changes in the commodity structure of exports and imports of agricultural products and food products of 2010, 2014 to 2016 (\%) 


\begin{tabular}{|c|c|c|c|c|c|c|c|c|c|c|}
\hline \multirow{3}{*}{$\begin{array}{l}\text { Goods (in accordance } \\
\text { with Ukrainian } \\
\text { Commodity Coding } \\
\text { System }\end{array}$} & \multicolumn{10}{|c|}{ Years } \\
\hline & \multicolumn{2}{|c|}{2012} & \multicolumn{2}{|c|}{2014} & \multicolumn{2}{|c|}{2015} & \multicolumn{2}{|c|}{2016} & \multicolumn{2}{|c|}{$\begin{array}{l}2016 \pm \text { to } \\
2010\end{array}$} \\
\hline & Exp & Imp & Exp & Imp & Exp & Imp & Exp & Imp & Exp & Imp \\
\hline $\begin{array}{l}\text { Live animals and } \\
\text { animal products }\end{array}$ & 7.8 & 21,6 & 6.1 & 18.6 & 5.7 & 15.7 & 5.1 & 16.1 & -2.7 & -5.5 \\
\hline Plant products & 40.0 & 27.1 & 52.4 & 33.5 & 54.7 & 32.9 & 53.0 & 33.0 & +13.0 & +5.9 \\
\hline $\begin{array}{l}\text { Animal fats and plant } \\
\text { oils }\end{array}$ & 26.3 & 7.8 & 22.9 & 5.0 & 22.7 & 5.2 & 25.9 & 6.3 & -0.4 & -1.5 \\
\hline Ready food products & 25.9 & 43.5 & 18.6 & 42.9 & 16.9 & 46.1 & 16.0 & 44.6 & -9.9 & -1.1 \\
\hline Total & 100 & 100 & 100 & 100 & 100 & 100 & 100 & 100 & $\mathrm{x}$ & $\mathrm{x}$ \\
\hline
\end{tabular}

Source: data of the State Statistics Service of Ukraine of 2010, 2014 - 2016 processed by the authors

Having explored the current trends in agricultural development, the formation of agrarian structures, other components of the agro-industrial activity, especially the level of life support for rural residents, it should be noted that the market economy system in the way in which it is now in Ukraine has its significant shortcomings and has so far proved to be unable to eliminate most of the negative phenomena, to prevent certain distortions in the formation of an effective system of market relations using national legislation and the effect of objective economic laws.

In this regard, we can illustrate only a few important trends, which, in our opinion, the public administration should pay special attention to.

In the context of dropping financial capacity of the population, according to the State Statistics Service of Ukraine, the caloric value of average daily consumption per person in 2016 amounted to $2742 \mathrm{kcal}$, which is $24 \%$ below the 1990 level and makes only $79 \%$ of the recommended general level for balanced nutrition. Also, the quality of the population's nutrition has been deteriorating due to the lack of actual consumption of such high-calorie foods as meat, dairy, fish, fruit and berry products, whose average annual consumption is only 55-68\% compared to the substantiated physiological norms. Given the unsatisfactory state of the food supply (physical and economic availability of quality food products), the state and businesses should take appropriate measures to change the structure of agricultural production that meets the criteria for food security. The ways of solving this most important task of agricultural policy should stimulate producers of the respective types of products and consumers to purchase such products. It would be advisable to use the experience of other countries. For example, in the US, using appropriate financial mechanisms and instruments, including the 
establishment of the Food Corporation, during the depression of the 1930s of the last century, such a system was developed that would enable a comprehensive solution to the problems of food security. And until now, measures to support farmers through the formation of a stable system of procurement of agricultural products from them enable integral stimulation of production by increasing the capacity of the domestic food market and, at the same time, solve social problems of the low-income population through subsidizing them. Note that such a system until now operates in this the most economically developed country in the world. Such regulation of the agricultural market does not contradict the principles of the WTO, improves the access of the population to important foodstuffs resources, does not distort the market and, importantly, positively affects the price situation. In Ukraine, during the years of independence, a significant decrease in the volume of production of livestock products occurred, in the first place, milk, cattle, pigs, sheep and other cattle. It should be noted that livestock breeding sector has been creating the basis of rational nutrition of the population for centuries, ensuring food self-sufficiency and income of rural residents, their employment, availability of organic fertilizers, etc. This is confirmed by the presence of livestock at various critical stages of the functioning of Ukrainian rural areas economy and its catastrophic decline during the years of Ukraine's independence (Table 2).

Table 2. Livestock in Ukraine (million cattle)

\begin{tabular}{|c|c|c|c|c|c|c|c|c|}
\hline \multirow[t]{2}{*}{ Animals } & \multicolumn{2}{|l|}{ Years } & \multicolumn{6}{|c|}{ As of 1 Jan 2017 (\% of) } \\
\hline & $\begin{array}{l}\text { As of } 1 \\
\text { Jan } \\
1916 \\
\text { (World } \\
\text { War I) }\end{array}$ & $\begin{array}{l}\text { As of } 1 \\
\text { Jan } 1940\end{array}$ & $\begin{array}{l}\text { As of } 1 \\
\text { Jan } 1946 \\
\text { (after the } \\
\text { end of } \\
\text { World } \\
\text { War II) }\end{array}$ & $\begin{array}{l}\text { As of } 1 \\
\text { Jan } 1990 \\
\text { (collapse } \\
\text { of } \\
\text { USSR) }\end{array}$ & $\begin{array}{l}\text { As of } 1 \\
\text { Jan } \\
2017\end{array}$ & $\begin{array}{l}\text { As of } \\
1 \text { Jan } \\
1916\end{array}$ & $\begin{array}{l}\text { As of } \\
1 \text { Jan } \\
1946\end{array}$ & $\begin{array}{l}\text { As of } \\
1 \text { Jan } \\
1990\end{array}$ \\
\hline Cattle & 9132.0 & 10996.1 & 8275.3 & 25194.8 & 3682.3 & 40.3 & 44.5 & 14.6 \\
\hline \multicolumn{9}{|l|}{ Including: } \\
\hline cow & 4115.0 & 5964.5 & 4312.2 & 8257.6 & 2108.9 & 51.2 & 48.9 & 25.5 \\
\hline pig & 6469.0 & 9185.8 & 2888.6 & 19946.7 & 6669.1 & 103.1 & 230.9 & 33.4 \\
\hline $\begin{array}{l}\text { sheep and } \\
\text { goat }\end{array}$ & 6904.0 & 7325.0 & 3389.8 & 9003.1 & 1314.8 & 19.0 & 38.8 & 14.6 \\
\hline horse & 6454.0 & - & 2000.0 & 738.4 & 291.5 & 4.5 & 14.6 & 39.5 \\
\hline
\end{tabular}

Source: data of the State Statistics Service of Ukraine of 1990 and 2017 processed by the authors

Actually, nowadays the increase in the number of cattle with high productive (competitive) potential is becoming a major factor in increasing the production of livestock products. At the same time, the increase in the stock of highly productive breeds of cattle is a complex scientific and production process associated with the 
development of a modern system of production of high-quality breeding products, timely development of modern technologies in livestock production and needs adequate funding. Without state support, such a challenge will be extremely difficult to solve in a short time.

Based on the recommendations of the Ukrainian Scientific Research Institute of Food Hygiene on the structure of rational nutrition, the dairy and meat and other products of animal origin at present prices should account for almost 50\% of the total value of the food basket. For example: in the Kyiv markets, prices of $1 \mathrm{~kg}$ lard during 2017 increased to $150 \mathrm{UAH}$, which is more than $10 \%$ of the minimum pension per month, which does not require any comments. The low paying capacity of the Ukrainian population, the bulk of which today can be qualified as the poor, objectively motivates the population to restrict the purchase of the most highly-priced products, which, in the first place, are dairy and meat products. Staffed retail of meat and dairy products clearly demonstrates actual low consumption of these products. In turn, such a situation essentially limits the capacity of the domestic market, and the insufficient state's attention to the creation of a reliable control system to guarantee the quality of dairy and meat products in accordance with the standards of the EU market or other developed countries, makes it impossible to export, which forces domestic producers to cut production of animal products. Moreover, low consumer demand for these products on the domestic market reduces producer prices and leads to loss-making (Table 3).

Table 3. Efficiency of livestock production in 2016, the consumption of which does not provide rational nutrition standards in Ukraine

\begin{tabular}{|c|c|c|c|c|c|c|c|}
\hline \multirow{2}{*}{$\begin{array}{l}\text { Types of } \\
\text { livestock } \\
\text { products, which } \\
\text { fail to provide } \\
\text { dietary intake } \\
\text { levels }\end{array}$} & \multirow{2}{*}{$\begin{array}{l}\text { Yearly } \\
\text { dietary } \\
\text { intake } \\
\text { levels } \\
\text { per } \\
\text { person } \\
(\mathrm{kg})\end{array}$} & \multirow{2}{*}{$\begin{array}{l}\text { Actual } \\
\text { con- } \\
\text { sumption } \\
\text { per } \\
\text { person } \\
\text { (kg) }\end{array}$} & \multirow{2}{*}{$\begin{array}{l}\text { Level of } \\
\text { provision } \\
(\%)\end{array}$} & \multirow{2}{*}{$\begin{array}{l}\text { Profitability } \\
\text { for } \\
\text { producers } \\
(\%)\end{array}$} & \multicolumn{3}{|c|}{$\begin{array}{l}\text { Capacity of domestic market } \\
\text { (1000 ton) }\end{array}$} \\
\hline & & & & & $\begin{array}{l}\text { at the } \\
\text { dietary } \\
\text { intake } \\
\text { levels }\end{array}$ & $\begin{array}{l}\text { actual } \\
\text { con- } \\
\text { sumption }\end{array}$ & \pm \\
\hline Meat products & 83 & 51.7 & 61.9 & $\mathrm{X}$ & 3544 & 2195 & -1349 \\
\hline $\begin{array}{l}\text { Including meat } \\
\text { of: }\end{array}$ & $\mathrm{x}$ & $\mathrm{x}$ & $\mathrm{X}$ & -24.8 & $\mathrm{X}$ & $\mathrm{x}$ & $\mathrm{X}$ \\
\hline \multicolumn{8}{|l|}{ cattle } \\
\hline pig & $\mathrm{x}$ & $\mathrm{x}$ & $\mathrm{x}$ & -4.5 & $\mathrm{X}$ & $\mathrm{X}$ & $\mathrm{x}$ \\
\hline poultry & $\mathrm{x}$ & $\mathrm{x}$ & $\mathrm{x}$ & 5.0 & $\mathrm{x}$ & $\mathrm{x}$ & $\mathrm{X}$ \\
\hline sheep and goat & $\mathrm{x}$ & $\mathrm{x}$ & $\mathrm{x}$ & -35.2 & $\mathrm{x}$ & $\mathrm{x}$ & $\mathrm{x}$ \\
\hline Milk & 380 & 209.5 & 55.1 & 18.2 & 162246 & 8995 & -7284 \\
\hline
\end{tabular}




\begin{tabular}{|l|c|c|c|c|c|c|c|}
\hline & & & & & & & \\
\hline Fish & 20 & 8.6 & 45.0 & -4.4 & 854 & 370 & -444 \\
\hline Eggs (number) & 290 & 267 & 92.0 & 0.5 & $\begin{array}{c}12.4 \\
\text { billion }\end{array}$ & $\begin{array}{c}11.4 \\
\text { billion }\end{array}$ & $\begin{array}{c}1.0 \\
\text { billion }\end{array}$ \\
\hline $\begin{array}{l}\text { Average for all } \\
\text { types }\end{array}$ & $\mathrm{x}$ & $\mathrm{x}$ & $\mathrm{x}$ & 24.9 & $\mathrm{x}$ & $\mathrm{x}$ & $\mathrm{x}$ \\
\hline
\end{tabular}

Source: data of the State Statistics Service of Ukraine of 2016 processed by the authors; dietary intake levels determined by Ukrainian RI of Food Hygiene

Also, the situation in livestock breeding is complicated by the loss of authority previously recognized by international organizations as a reliable domestic system of veterinary medicine, which should not only perform inspection but also prophylactic, anti-epizootic and other functions. In recent years, the violation of anti-epizootic and prophylactic measures has already led to an additional loss of livestock due to various diseases. Therefore, we get a continuous circle of problems that objectively cause the decline of an extremely important area of agricultural activity in Ukraine.

A similar situation is also associated with a significant decline in the production of traditional individual crop products, in relation to which Ukraine has favourable natural and economic conditions, and in the recent past occupied a significant place in the world, such as sugar beet, fruit, grapes, melons, flax, hops, hemp (fiber), and tobacco (Table 4).

Table 4. Dynamics of production volumes of important types of crop production, where potential market opportunities are being lost (1000 tons)

\begin{tabular}{|l|l|l|l|l|l|}
\hline \multirow{2}{*}{ Products } & \multicolumn{4}{|c|}{ Years } & 2015 (\% of \\
\cline { 2 - 6 } & 1990 & 2000 & 2010 & 2015 & $1990)$ \\
\hline Sugar beet & 44264.5 & 13198.8 & 13749.2 & 10331 & 23.3 \\
Fruits & 2770.5 & 1319.4 & 1541.4 & 1907.4 & 68.8 \\
Grapes & 835.7 & 513.8 & 521.9 & 386.3 & 46.2 \\
Watermelon & 753.0 & 325.3 & 626.5 & 460.7 & 61.2 \\
Long-stalked flax & 108.1 & 8.3 & 0.4 & 1.0 & 0.9 \\
Hops & 5.5 & 0.7 & 0.8 & 0.3 & 5.5 \\
Hemp (fiber) & 6.5 & 1.5 & - & 0.5 & 7.6 \\
Tobacco & 12.4 & 3.0 & 3.0 & 0.3 & 2.4 \\
\hline
\end{tabular}

Source: data of the State Statistics Service of Ukraine of 2000 and 2015 processed by the authors

Such statistical studies point to significant unused potential opportunities even for production volumes already achieved in previous periods. These trends undoubtedly require changes in the state policy in stimulating the development of the critical crop and livestock sectors, the search for markets, the introduction of a supportive pricing policy, etc. 
The next major problem hampering the development of the agrarian sector is the continuation of the moratorium on the introduction of a market turning of agricultural land, which, according to various estimates, caused much damage to the state, business entities, villagers, and rural communities. Due to the impossibility of using land assets as the basic economic factor of competitive agricultural activity, the development of the agrarian sector is significantly hampered: the search for business partners and the use of additional sources of financing are complicated by mastering mechanisms of land mortgage lending and attracting investments, the problems of social protection of land owners, protection of lands, preservation of soil fertility, etc. This has already led to the situation where Ukrainian chernozem, recognized as one of the most fertile lands in the world, now have a humiliatingly low price. Moreover, such actions of the state violate the constitutional rights of villagers who are the shareholders of land plots, of which more than 1 million have already died and will never be able to use their property to solve life's problems, and 1.7 million shareholders are now at the age of over 70 . The state illegally continues to restrict the full right of peasants to own land for agricultural purposes, which have long been not state-owned. Such an artificial situation significantly limits the economic freedom of the villagers and in some way resembles serfdom. Has any politician ever asked themselves that practically $40 \%$ of villagers that own land plots will no longer be able to use the land to solve their own socio-economic needs, having all the constitutional rights, as it works in almost $99 \%$ of the world?

The introduction of the agricultural land market has now become a complicated and extremely politicized problem for Ukraine. Over15 years has been lost since the adoption of the Land Code of Ukraine, which in 2002 required the authorities within 3 months to adopt the relevant legislative acts for the staged development of market land relations. During this time, there was a lot of institutional, political, economic, social and other changes. Unfortunately, the interests of villagers and other small producers, rural communities over time moved on to the second place. There were influential monopoly structures for which the situation with such uncertainty at this stage is profitable. Instead, moratoria are introduced and unproductive discussions continue, there is a large number of draft laws on this issue, most of which contain diametrically opposed proposals, which clearly outline the lobbying of relevant interests, etc. In the scientific environment, given this situation, there is the opinion that the introduction of an ill-considered land market may lead to even more negative trends that will be practically impossible to stop in the future. At the same time, the introduction of a market turnover of agricultural land in a market economy is an objective necessity. Continuous hampering of this process generates other negative 
phenomena that are the progress of the shadow circulation, the uncontrolled concentration and redistribution of land ownership, insufficient attention to the protection of land and soil fertility, loss of ownership by villagers, etc. But the most important thing is that today, according to various estimates, a balanced land reform is still able to preserve the village and villagers that are the bearers of Ukrainian identity, traditions, culture and spiritual values.

Therefore, public authorities need to be consistent and uncompromising in shaping market land relations, the main principle of which should be to protect the interests of villagers and rural communities. According to the majority of experts, instability of the system of state support and taxation of agricultural producers as the basic level of agro-industrial activity and their financial and credit support system are the next important factors that restrain the effective development of the agrarian sector.

In recent years, supporting the development of the agrarian sector is complicated by the crisis of the state budget. There are many reasons, including shadow economy, corruption, unfair competition, hostilities and many others. In 2012, according to the Ministry of Agrarian Policy and Food, the volume of direct expenditures in support of agricultural development from the State Budget amounted to 9.044 billion UAH but in 2016, only 310 million UAH was absorbed. Along with the cut of budget support, the tax burden on the agrarian sector, especially on agriculture, which in recent years has received the greatest growth in obligations for the payment of various types of taxes, in comparison with other sectors of the national economy, is significantly increasing.

According to the State Fiscal Service of Ukraine, in 2016, entities of entrepreneurship in the agrarian sector paid 94 billion UAH for various types of land use allowances, of them, agricultural producers 27.8 billion UAH, respectively 2 and 4.2 times more than in 2012, while tax revenues in the state as a whole grew by 1.8 times during this period, including 1.7 times the tax and personal income tax (Table 5).

Table 5. Dynamics of tax payment to the consolidated budget by agricultural enterprises from 2014 to 2016 (million UAH)

\begin{tabular}{|l|l|l|l|l|c|}
\hline \multirow{2}{*}{$\begin{array}{l}\text { Branch of agricultural } \\
\text { sector }\end{array}$} & \multicolumn{4}{|c|}{ Years } & \multirow{2}{*}{$\begin{array}{c}\text { 2016 (\% } \\
\text { до 2012) }\end{array}$} \\
\cline { 2 - 5 } & 2012 & 2014 & 2015 & 2016 & 422.1 \\
\hline $\begin{array}{l}\text { Agriculture and } \\
\text { hunting }\end{array}$ & 6604.3 & 7329.2 & 12046.5 & 27876.7 & 332.1 \\
\hline $\begin{array}{l}\text { Forestry and timber } \\
\text { harvesting }\end{array}$ & 1091.6 & 1211.7 & 2227.0 & 3625.2 & 177.8 \\
\hline Fishery & 65.2 & 47.6 & 70.9 & 115.9 & 161.1 \\
\hline $\begin{array}{l}\text { Food and processing } \\
\text { industry }\end{array}$ & 38736.1 & 39722.4 & 45386.4 & 62388.6 & \\
\hline
\end{tabular}




\begin{tabular}{|l|l|l|l|l|r|}
\hline $\begin{array}{l}\text { Total in agricultural } \\
\text { sector }\end{array}$ & 46497.2 & 48310.7 & 59730.8 & 94006.4 & 202.2 \\
\hline $\begin{array}{l}\text { Tax revenues in } \\
\text { general on the state }\end{array}$ & 360567.2 & 367511.9 & 507635.9 & 650781.7 & 180.5 \\
\hline $\begin{array}{l}\text { Taxes and personal } \\
\text { income tax deductions } \\
\text { excluded }\end{array}$ & 297474.8 & 292309.0 & 407652.7 & 511999.9 & 172.1 \\
\hline
\end{tabular}

Source: data of the State Statistics Service of Ukraine of 2016 processed by the authors

Such state tax policy points to the discrimination of agriculture, which is the basic link in the food supply of the state, and in recent years, even under such conditions, provides a positive growth rate. The increase in the tax burden of agricultural producers in 2016 was due to the following:

- introduction of new taxes on the non-residential real estate, such as livestock and other production facilities;

- raising the rates of a fixed agricultural tax and replacing the tax system with a single tax;

- increase in the tax rates for vehicles;

- increase in taxation of alcoholic beverages and tobacco products;

- grant the right to local self-government bodies to independently determine the rates of land tax;

- introduction of a military fee.

The greatest increase in tax burden was caused by changes in VAT rates, which provided for the phased abolition of benefits from this type of taxation, while for almost 17 years this tax was charged but not paid to the state budget; agricultural producers remained in place to replenish their own turnover funds and acted as a guaranteed and significant component of their targeted state financial support. It should be noted that the previous system of fixed agricultural tax and VAT operated in a simplified regime and excluded any interference of tax authorities in the economic activity of agricultural producers. It was already in line with the principles of deregulation, which is now the basis for improving public policy. It should be emphasized that in previous years, for obtaining loans from the World Bank and the IMF, as well as for Ukraine's accession to the WTO, these international organizations were fully aware of the arguments of the Ukrainian side regarding the expediency of maintaining a system of state support through preferential taxation of agricultural producers. On the recommendations of international institutions, some changes were made to subsidies for milk and meat delivered on processing enterprises, contributions to the Pension and other social funds from the fixed agricultural tax are excluded. In general, this kind of taxation had no longer had any remarks by the international organizations. Consequently, some unclear manipulations on the part of the public authorities on financial policy 
seem to take place, which significantly worsens the functioning of the vital sector of the national economy.

In the situation of instability of budget support, the abolition of tax benefits, the objective of financial support for the development of the agricultural sector is objectively the intensification of the attraction of credit resources and investments. But the excessive cost and considerable limitation of the liquid collateral of agricultural producers considerably complicate the access to credit resources.

In addition, the agricultural sector of the economy, in particular, agriculture, in recent years is mainly provided with material and technical resources of foreign origin, which requires spending cash in foreign currency or calculations taking into account the change in the equivalence of currencies.

This includes agricultural machinery and its maintenance, plant protection products, large volumes of mineral fertilizers, seeds, veterinary medications and feed additives, etc.

Research shows that, at first sight, the agricultural sector in recent years seems to have intensified the attraction of loans, the volume of which in comparison with 2008 increased 1.9 times. At the same time, real lending based on the devaluation of the national currency, according to the National Bank of Ukraine, for this period decreased more than twice, and for agriculture 2.5 times (Table 6).

Table 6. Change in volume of lending to business entities in the agricultural sector as of 1 Jan 2009 and 1 Jan 2015 adjusted for devaluation of the national currency compared to US dollar

\begin{tabular}{|l|l|l|l|l|l|l|c|}
\hline \multirow{2}{*}{$\begin{array}{l}\text { Economic } \\
\text { activities of } \\
\text { agricultural } \\
\text { sector }\end{array}$} & \multicolumn{3}{|c|}{$\begin{array}{l}\text { Requirements of banks on loans granted to business entities } \\
\text { of the agricultural sector }\end{array}$} & $\begin{array}{l}\text { Change in } \\
\text { volume of } \\
\text { lending (US } \\
\text { dollar) \% }\end{array}$ \\
\cline { 2 - 8 } & \multicolumn{3}{|c|}{ as of 31 Dec 2009 } & \multicolumn{2}{|c|}{ as of 31 Dec 2015 } \\
$\begin{array}{l}\text { Agriculture, } \\
\text { forestry and } \\
\text { fishery }\end{array}$ & 29.4 & 5.27 & 5.28 & 48.4 & 21.84 & 2.22 & 40.9 \\
\hline $\begin{array}{l}\text { Production of } \\
\text { food products and } \\
\text { beverages }\end{array}$ & 27.8 & 5.27 & 5.28 & 60.8 & 21.84 & 2.78 & 52.7 \\
\hline $\begin{array}{l}\text { Manufacture of } \\
\text { tobacco products }\end{array}$ & 0.3 & 5.27 & 0.06 & 2.8 & 21.84 & 0.13 & 216.7 \\
\hline $\begin{array}{l}\text { Total in } \\
\text { agricultural } \\
\text { sector }\end{array}$ & 57.5 & 5.27 & 10.92 & 112.0 & 21.84 & 5.13 & 47.0 \\
\hline
\end{tabular}

Source: data of the National bank of Ukraine processed by the authors

The results of such actions, as compared to 2012, only led to a significant financial resource expense, due to the curtailment of direct financial support for agricultural producers through state budget expenditures, the abolition of the 
preferential VAT and fixed agricultural tax and the reduction of real crediting, taking into account the devaluation of the national currency. Undoubtedly, these trends have a negative impact on the efficiency of farming in the agricultural sector.

The way out of such a difficult financial and economic situation will objectively force agricultural producers to raise prices for their products, which is happening lately. However, this is a direct way to destabilize the food market and social instability, which must not be allowed. On this occasion, another, perhaps remote, the problem is emerging. Ukraine, in accordance with the Association Agreement, objectively tries to intensify the export of agricultural products and food products to the European market. Such a vector of national policy is the most grounded and logical. At the same time, the repeated lagging behind the level of state support of agriculture in Ukraine from support in EU countries puts domestic agricultural producers in uncompetitive conditions. For example, support for the development of agriculture and rural areas in Poland, according to the data of the Rural Development Program (2014 - 2020), at the expense of the state budget and the EU funds is a total of 13.5 billion euros. Such funding is directed at the following areas: support for the development of agriculture and entrepreneurship (46\%), territorial development (14.4\%), knowledge transfer and innovation (1.4\%), product quality support (0.3\%), ecology and ecological agriculture (32.2\%), technical assistance and structural pensions (5.7\%).

In accordance with the course of the national currency of Ukraine to the European (September 2017), such overall support for agriculture and rural areas in Poland is estimated in the amount of 420 billion UAH, that is 60 billion UAH per year, while in Ukraine, such measures in 2016 were funded with 310 million UAH. This is despite the fact that the territory of Poland is almost twice less than the territory of Ukraine.

Such striking differences indicate that Ukrainian producers, in comparison with Polish and European ones in general, will stand in the European market in different weight categories (similar to different football leagues or weight categories in boxing), and their competitiveness is compelled will be supported by a reduction in the level of salaries and other social benefits, violation of the required level of technical support by the relevant resources, artificial limitation of profitability, which may at all lead to loss of opportunity to restore domestic agricultural production.

If these factors are not taken into account in public policy, the agricultural sector may find itself in even more difficult financial and economic conditions. Unfortunately, such examples of inconsistencies in government policy generate these and other negative trends. In particular, this concerns the regional aspects of 
agricultural development, exploitation reclaimed land, the unsatisfactory state of preservation of land soil fertility, the decadence of rural areas, etc. Being a member of the WTO, the International Organization for Food and Rural Development (FAO), and many other European and world unions and organizations encourage Ukraine to work in accordance with international rules of market relations.

In these circumstances, taking into account the current state and trends, it becomes clear that without significant modernization of the state agricultural policy, the reliance on the efficient development of the agricultural sector and solving problems in rural areas will be extremely difficult.

\section{Conclusions}

Effective integration into the global food system, creating conditions for the competitive development of the agricultural sector and addressing the problems of rural development are impossible without systematic modernization of agricultural policy by maximizing adaptation of domestic legislation to European standards for agrarian business and rural development.

Now, state agricultural policy must first of all be aimed at solving social and economic problems of rural population, streamlining the agricultural system, developing land reform, protecting land, preserving soil fertility, protecting the natural environment, reviving livestock, improving tax and fiscal policies, providing efficient mechanisms of agrarian market regulation, the growth of agricultural and industrial production on the basis of innovation development, implementation of measures to restrict monopolies, unfriendly competition, and shadow economic relations.

Positive results in state agricultural policy can be achieved by balancing tasks and priorities in the event of the implementation of appropriate state measures and mechanisms and adherence to certain principles, rules, incentives, and restrictions.

\section{Bibliography}

1. Andriichuk, V. G., Zubets, M. V. \& Yurchyshyn, V. V. (2005). Suchasna ahrarna polityka: problemni aspekty (Modern agrarian policy: problematic issues). Kyiv: Ahrarna nauka. [in Ukrainian]

2. Gaidutskyi, P. I. (2015). Kuchma's agricultural reform in Ukraine: historical and economic aspects. Ekonomika APK (Economy of agroindustrial complex), 1, 5-13. [in Ukrainian]

3. Heiets, V. M. (2016). Economy of Ukraine: key problems and prospects. Ekonomika I prohnozuvannia (Economy and Forecasting), 1, 7-23. [in Ukrainian] 
4. Gubeni, Yu. E. (2015). Aspects of agribusiness internationalization in the identification of food security. In Pratsi mizhnarodnoi naukovo-praktychnoi konferentsii "Suchasni problem ta perspektyvy mizhnarodnoi intehratsii ahrarnoho sektoru ekonomiky Ukrainy" [Proceedings of International research and practice conference "Modern problems and prospects of international integration of agricultural sector of economy of Ukraine”] (pp. 90-94). Kyiv: NNTs "IAE”. [in Ukrainian]

5. Hladii, M. V., Kropyvko, M. F., Bulavka, O. H. \& Sabluk, P. T. (Ed.) (2011). Upravlinnia kompleksnym rozvytkom ahropromyslovoho vyrobnytstva i silskohospodarskykh terytorii [Management of integrated development of agroindustrial production and agricultural territories]. Kyiv: NNTs "IAE". [in Ukrainian]

6. Dudar, V.T. (2016). Food security of Ukraine and its components in the context of state economic security. Visnyk TNEU [Bulletin of Ternopil National Economic University], 2, 20-30. [in Ukrainian]

7. Kyrylenko, I. H. (2008). Transformatsiia sotsialno-ekonomichnykh peretvoren u silskome hospodarstvi Ukrainy [Transformation of socio-economic transformations in agriculture in Ukraine: problems, prospects]. Kyiv: NNTs “IAE”. [in Ukrainian]

8. Kropyvko, M. F. (Ed.), Nemchuk, V. P. \& Rossokha, V. V. (2008). Orhanizatsiia upravlinnia ahgarnoiu ekonomicoiu [Organization of management of agricutural economy]. Kyiv: NNTs "IAE”. [in Ukrainian]

9. Lupenko, Yu. O., Sabluk, P. T., Mesel-Veseliak, V. Ya. \& Fedorov, M. M. (2014). Results and problems of agricultural reform. Ekonomika APK [Economy of agroindustrial complex], 7, 26-38. [in Ukrainian]

10. Mazaraki, A. A. (Ed.), Krolchuk, O. P. \& Melnuk, T. M. (2010). Ekonomichna bezpeka $v$ umovakh hlobalizatsiinykh vyklykiv [Economic security in the context of globalization challenges]. Kyiv: National Economical University. [in Ukrainian]

11. Malik, M. Y. \& Shpykuliak, O. H. (2011). Institutes and institutions in the development of the agricultural economic sector. Ekonomika APK [Economy of agroindustrial complex], 7, 169-177. [in Ukrainian]

12. Mesel-Veseliak, V. Ya. \& Fedorov, M. M. (2016). Strategic directions of development of Ukrainian agricultural sector. Ekonomika APK [Economy of agroindustrial complex], 6. 37-49. [in Ukrainian] 
13. Sabluk, P.T. (2015). Status and directions of agricultural reform development. Ekonomika APK [Economy of agroindustrial complex], 2, 10-17. [in Ukrainian]

14. Sabluk, P. T. (2011). Main directions of improvement of the Ukrainian state agrarian policy. Ekonomika APK [Economy of agroindustrial complex], 5, 3-16. [in Ukrainian]

15. Statistical yearbook "Agriculture of Ukraine” 2010 to 2016. Prokopenko Retrieved from http://www.ukrstat.gov.ua/ [in Ukrainian]

16. Statistical data of the National Bank of Ukraine. Retrieved from https://bank.gov.ua/control/uk/publish/article?art id=65162\&cat id=36674 [in Ukrainian]

17. Paskhaver, B.Y. (2001). Food availability. Ekonomika Ukrainy (Economy of Ukraine), 7, 69-77. [in Ukrainian]

18. Khorunzhyi, M. Ya. (2003). Food safety: socio-economic essence, status and indicators. Ekonomika APK [Economy of agroindustrial complex], 6, 9-16. [in Ukrainian]

19. Yurchyshyn, V. V. (2013). Suchasni ahrarni peretvorennia v Ukraini [Modern agricultural transformation in Ukraine]. Kyiv: Institute of Economics and Forecasting NAAS of Ukraine. [in Ukrainian] 